\title{
Problems of Surviving and Growth of New Ventures: Literature Review
}

\section{Egor Vasilevich Skaleckii}

Phd student, junior researcher, "Laboratory management and control systems", Far Eastern Federal University Russian Federation, 690950, Vladivostok, Sukhanova Street, 8; skaletskiy@yandex.ru

\section{Artur Rubikovich Nagapetyan}

Phd student, junior researcher, "Laboratory management and control systems", Far Eastern Federal University Russian Federation, 690950, Vladivostok, Sukhanova Street, 8; art9309@mail.ru

\section{Jakhongir Khalimovich Khamdamov}

Phd student, junior researcher, "Laboratory management and control systems", Far Eastern Federal University Russian Federation, 690950, Vladivostok, Sukhanova Street, 8; jakhongir85@gmail.com

\section{Anton Sergeevich Glupak, Phd Student}

Vladivostok State University of Economics and Service, Russian Federation 690000, Vladivostok, Gogol Street, 41; 1grok@mail.ru

\section{Doi:10.5901/mjss.2016.v7n2p212}

\section{Abstract}

This work represents the results of analysis of researches devoted to problem of high death level of new ventures. This work is based on the articles published in journals indexed by Scopus, Web of Science. The primary goal of this article is to systemize all the investigations of new ventures threats. Literature analysis shown that authors attribute infant administrative system, lack of financial resources due to low level of market information efficiency in relation to the small company, lack of stable links with external agents, lack of interest from potential employees to the most widespread problems specific for new ventures, which lead to high risk of bankruptcy. Despite the different focuses all the authors suggest that high levels of threats are temporary and decrease over the time. In the discussion the authors examine the role of financial market infrastructure in the context of overcoming the identified survival and development problems of small firms in the process of their legitimization.

Keywords: entrepreneurship, new ventures growth, liability of newness, financial infrastructure, liability of smallness, liability of adolescence, CAPM, information asymmetry, risks

\section{Introduction}

Entrepreneurship is a powerful economic force, creating a majority of new workplaces, fostering economy growth, which determines governmental interest to this phenomenon. Steady growth of small and medium enterprises reflects stability of the economy. Moreover, small firms easier adapt to external changes and market demand, which allows them to be flexible and generate innovations, filling emerging gaps in the market. Thus, we are able to consider entrepreneurship is a core part of market innovative economy. At the same time, entrepreneurship is highly attractive topic for academic researchers. Despite the shaping concept of entrepreneurship is not completed, there is an increasing interest to it from researchers [Wiklund et al, 2011]. During the evolution of the research field "entrepreneurship" ceased to be a separate discipline and joined the group studies on the business focusing in various aspects of the creation and of new firms. However, at the same time, most of the startups are not innovative and they generate a limited amount of added value. A small group of new ventures, concentrating on innovative development, creates the lion's share of new value. Actually, government is interested in support of new ventures with high growth aspirations [Shane, 2009]. High rate of internal dynamism enables them transform in a quickest way in order to satisfy market demand, which fosters rapid growth.

From the other side, high volatility leads to lower survival rate, which is inherent for new ventures. Success of the venture is highly depends on how the initial liabilities were overcame. This fact calls to more detailed researching of the threats for new ventures. Better understanding of nature of these liabilities can mitigate level of threat of initial periods of 
firm`s activity. This way, the aim of current study is to detect historical logic of development of researching liabilities for new ventures and systemize them.

In order to implement this aim, the following tasks need to be addressed to achieve this aim: the selection of articles for the literature review, selecting the most significant articles on the basis of reference analysis, classifying of researches in order to underline the positions of key researchers in this sphere and constructing a model of theory development. The structure of article is the following. In the introduction authors develop the problem and purpose of the study. They further justify the research methodology. In the analysis and results section the literature is studied and the basic research position in the context of the goal is given. In the findings and implications, the authors express their views about the place of the financial infrastructure in the context of overcoming problems of survival and development of small firms. Finally, in the last passage conclusions and literature are given.

\section{Literature Review}

The appearance of entrepreneurship as a scientific term is connected with scientific works of J. Schumpeter. According to his approach, entrepreneurship is a process of creating new value through the combining of available resources [Schumpeter, 2008]. The next milestone in the entrepreneurship is connected with I. Kirzner, who considered entrepreneurship as a process of finding and filling the gap in the market for gaining profit [Kirzner, 1973].

As we can notice, despite the different focuses both approaches to entrepreneurship identify the availability of resources as a starting point for new venture's development. However, new ventures are limited in resources and they exposed to higher risks. Analysis of scientific literature enabled us to distinguish some combinations of complex threats for the firms: liability of newness, liability of smallness, liability of adolescence and liability of foreignness [Aldrich and Fiol, 1994].

The first researches of phenomena of a high death rate for new ventures appeared in the middle of XX century. In 1965 A. Stinchcombe published his path-breaking article, in which he used concept of liability of newness for explanation of high death rate among new ventures [Stinchcombe, 1965]. This concept includes a set of reasons leading to it.

\section{Research Methods}

To achieve the stated objectives, authors conducted searching for the articles from the databases Web of Science and Scopus, devoted to the problems of survival and growth of new firms. On the initial stage we have organized search based on keywords "liabilities" and "new ventures". Further after looking through the abstracts non-relevant articles were eliminated from the sample. Selection of articles was carried out in the context of building a systematic approach to the formation of the historical development of views on the development of small firms on one hand. On the other hand, the authors tried to select articles that allows you to construct a comprehensive model of functioning of small firms in the context of risks to its survival.

Based on the comparative method we identified the four conceptions of liabilities, which reflect core problems, inherent for new ventures. They are following: liability of newness, liability of foreignness, liability of smallness, liability of adolescence. Further, we selected the articles in which these conceptions were presented at first time and design them in a chain of consistent elements in order to follow the dynamics of theory development. As a result we received a model of theory development with wide description of the each concept.

\section{Analysis Results}

Firstly, positioning on the market causes high financial and time costs, directed to gaining market share and creating a positive image of brand among the potential clients. Secondly, lack of tangible and intangible assets strictly limits the new venture's potential an implementing a wide range of strategies. Firms are forced to bear in mind the limitations in disposable human, social and financial resources operating in the market, which negatively affects the potential outcomes. Thirdly, venture's efficacy is low due to absence of stable networks and segregation of responsibilities within the working team. A lack of established routines leads to organizational delays, duplication of functions and, consequently, decreases overall efficiency. Moreover, infancy of external links negatively affects firm's capability for involvement in market process and attraction of investments. During the new venture's development the liability of smallness is constantly declining [Stinchcombe, 1965].

Concept of liability of smallness was further investigated in Hannan's and Freeman's works with using of ecological approach. According to this approach, the unit of analysis is not a separate firm, but a set of new ventures, 
considering as a population. Results showed that the lowest death rate was demonstrated not by the most effective ones, but by new ventures with high indexes of internal inertia. Established organizational structure along with settled routines enables firm to reproduce itself. This feature is a key indicator of ability to survive. Consequently, dynamism inherent for new ventures on the early stages of lifecycle in long-term periods destructively influences the firm's activities, hindering the reproduction processes. During the firm's maturing internal inertia increases primarily due to expansion of bureaucracy in order to better control firm`s activity. As a result, firm ability to survive increases [Hannan and Freeman, 1984].

Concept of liability of newness has the similarities with the consideration of firm 's on the first stages in the lifecycle theory. I. Adizes explains the high death level of new ventures as a result of infancy of administrative system. Dynamism, caused by it can lead as to steady growth as to bankruptcy [Adizes, 1979].

If we consider international new ventures, we can define that they have a specific type of liabilitiy which is similar to liability of newness. At the beginning of internationalization, an entrepreneur is subject to the liability of foreignness (Hymer, 1976) which stems from doing business outside the venture's home country. This liability means that the global entrepreneur may incur higher costs than local (host country) competitors due to high transaction and coordination costs in a host country [Zaheer and Mosakowski 1997]. After receiving an expirience and optimization of logistics in host country liability of foreignness strictly decreases.

Further investigation identified one more threat for new ventures, which was called liability of smallness. Authors of this term as in liability of newness consider limitation of finance resources and infancy of bureaucracy. However, they consider as a key premise smallness instead of newness. In this case, the most crucial problem is an attraction of human capital as far as the most promising employees prefer big firms with great opportunities of implementing career growth inside the firm. Also small ventures are not target audience for banks and other credit organizations [Aldrich and Auster, 1986].

Another point of view on the problem of high death rate of new ventures was adopted by Schussler. Authors oppose conception of liability of adolescence to liability of newness, suggesting that risk of death for new ventures can be described not by strictly decreasing linear function, but by inverted parabola with peak after some months after start of business. Authors argue that start-ups have enough financial resources from initial capital. So, it is logical that potential business owner makes decision about start new venture, having some amount of money for predictable spending. Moreover, absence of obligations and disputes with external parties enables for venture to consider wide range of opportunities. After, first market shocks, financial resources of venture can be exhausted, so it leads to default to external parties and, as a result, to higher possibility for firm to go out of business. After overcoming the peak period, the liability of adolescence decreases [Bruderl, 1990]. Table 1 below provides a succinct summary of threat research for new firms.

Table 1. A brief summary of the researches

\begin{tabular}{|c|c|c|c|}
\hline Concepts and theories & Year & Authors & The risk of mortality \\
\hline Liability of newness & 1965 & Stinchcombe A. & $\begin{array}{r}\text { The greatest risk inherent in any new business. Throughout the life cycle } \\
\text { mortality risk is monotonically decreasing. }\end{array}$ \\
\hline Liability of foreignness & 1976 & Hymer & $\begin{array}{c}\text { The highest levels of risks is common for international ventures, starting their } \\
\text { activity abroad. After optimization of logistics it decreases }\end{array}$ \\
\hline Liability of smallness & 1986 & Aldrich H., Auster E. & $\begin{array}{r}\text { The maximum level of risk associated with small enterprises; the greater the } \\
\text { growth the lower the degree of risk }\end{array}$ \\
\hline Liability of adolescence & 1990 & Bruderl J., Schussler R. & $\begin{array}{l}\text { The peak value of risk is achieved as the exhaustion of the initially available } \\
\text { resources; with the advent of stable capital flows to the firm risk decreases. }\end{array}$ \\
\hline
\end{tabular}

\section{Discussion}

The integration of the concepts of liability of newness, liability of foreignness, liability of smallness, liability of adolescence can be implemented on the platform need to reach the firm legitimacy. Generalizing outcomes of all approaches mentioned above each new venture strives to achieve legitimacy to become more stable in market environment. Legitimacy can be defined as a relation between the firm 's activities and what is accepted, endorsed and implemented through formal and informal institutions of the social system in which there is a firm operates [Zimmerman and Zeith, 2002]. Achieving of legitimacy strongly influence the character and density of contacts with external agents. In other words, legitimacy reflects subjective perception of the venture by other market participants. A. Stinchcombe mentioned lack of legitimacy among the reasons for liability of newness, but he did not distinguish it a cornerstone of a concept [Stinchcombe, 1965]. Further investigations of surviving and growth of new ventures underline role legitimacy as factor, 
influencing the attraction of financial, human and social capital [Aldrich and Fiol, 1994; Zucker, 1987].

In the formation of legitimacy plays a key role of the firm with external agents. In other words, legitimacy is a mediator between the investor and the entrepreneur, being the subjective component in relation to the company. It is important to note that in today's economic environment, financial infrastructure provides not just access to financial resources, but also it is the most important institution in the context of building trusting relationships with all stakeholders, namely employees, investors, and other partners and contractors. Financial infrastructure determines the ability and the opportunity to legitimize small companies.

Considering current researches in finance sphere, we are able to pay attention to the Roll [Roll, 1981]. He investigated the problem of adequacy of using Capital assets pricing model (CAPM) for small enterprises. By using this model investors estimate risks and, this way, compare attractiveness of investing in different firms. However, there is a lack of available information about new ventures for estimation of potential risks and using of this information may lead to unsatisfactory results. It causes high levels of informational asymmetry in relationships between owners of new ventures and investors [Akerlof, 1970].

Development of the small firm legitimacy depends on the market information efficiency in relation to it. Information efficiency is achieved, including through overcoming value pricing deformation in finance market [Nagapetyan et al, 2015].

The result of achieving legitimacy is steady firm growth. Nevertheless, some owners of small ventures oriented to small niche markets without hostile competition in them does not focus on growth. However, majority of business owners strives to growth. Achievement of steady growth makes firm more attractive for external agents, which leads to growth of flow of human, financial and social resources.

\section{Conclusion}

New firms is widely recognized as the "locomotive" of the economy development because they generate economic growth, creating jobs. Therefore, it is very important to identify the conditions necessary for the creation and survival of enterprises. This article focused on the problem of survival because of a high mortality rate of new firms.

An analysis was conducted of development studies, explains the higher mortality rate among new firms. Based on the analysis the data has been grouped in a chronological order, allowing to monitor the development of the theory. The scientific novelty of the work is determined by the extension of the concept of legitimization, by adding to the model the interim unifying platform - financial infrastructure. This platform not only allows to attract financial resources, but also is a key component in the process of overcoming information asymmetry around the new company, allowing her to build trusting relationships with all stakeholders. This is defined by us as a key outcome of the process of legitimization.

The results of this article can be used as a theoretical basis for writing the dissertation research and conduct empirical studies of entrepreneurship. The main constraints in job we see into an abstract interpretation of the process of legitimization and its financial infrastructure. In further studies, these limitations can be overcome through a better understanding of existing linkages and interdependencies, and experimental data validation.

\section{Acknowledgments}

The study was supported by the "Supportive program for perspective PhD students"of Far astern Federal University (FEFU).

\section{References}

Akerlof, A. (1970) The Market for "Lemons": Quality Uncertainty and the Market Mechanism. The Quarterly Journal of Economics, 84, 488-500. DOl:http://dx.doi.org/10.2307/1879431

Adizes, I. (1979) Organizational passages - Diagnosing and treating lifecycle problems of organizations. Organizational Dynamics, 8.1, 3-25. DOl:http://dx.doi.org/10.1016/0090-2616(79)90001-9

Aldrich, H., Auster, E. (1986) Even dwarfs started small: Liabilities of size and age and their strategic implications. Research in Organizational Behavior, 8, 165-198.

Aldrich, H., Fiol, C. (1994) Fools rush in? The institutional context of industry creation. Academy of Management Review, 19, 645-670. DOl:http://dx.doi.org/10.5465/AMR.1994.9412190214

Bruderl, J., (1990) Schussler R.Organizational mortality: the liabilities of newness and adolescence. Administrative Science Quarterly, 35, 530-547.

Bystrova, Y., Shirokova, G. (2014) What do we know about young entrepreneurial firms? Definitions, characteristics and factors affecting 
growth. Sovremennaya konkurentsiya, 6, 61-93.

Garnsey, E., Stam, E., Heffernan, P. (2006) New firm growth: Exploring processes and paths. Industry \& Innovation, 13, 1-20. DOl:http://dx.doi.org/10.1080/13662710500513367

Hannan, M., Freeman, J. (1984) Structural inertia and organizational change. American Sociological Review, 49, 149-164. DOl:http://dx.doi.org/10.2307/2095567

Hormiga, E., Batista-Canino, R.M., Sanchez-Medina, A. (2011) The Impact of Relational Capital on the Success of New Business StartUps. Journal of Small Business Management, 49, 617-638. DOl:http://dx.doi.org/10.1111/j.1540-627X.2011.00339.X

Hymer, S. H. (1976). The International Operations of National Firms: A Study of Direct Investment. MIT Press, Cambridge, MA.

Kirtzner, I. (1973) Competition and Entrepreneurship Chicago: University of Chicago Press.

Nagapetyan, A., Rubinstein, E., Urumova, F. (2015) The development of modern portfolio theory: pricing deformation and arbitration. Bulletin of the Institute of Economics of Russian Academy of Sciences, 3, 106-115.

Roll, R. (1981) A Possible Explanation of Small Firm Effect. The Journal of Finance, V.36, 879-888. DOl:http://dx.doi.org/10.1111/j.15406261.1981.tb04890.x

Shane, S. (2009) Why encouraging more people to become entrepreneurs is bad public policy. Small Business Economics, 33, 141-149. DOl:http://dx.doi.org/10.1007/s11187-009-9215-5

Shane, S., Venkataraman, S. (2000) The promise of entrepreneurship as a field of research. Academy of management review, 25, 217226. DOI:http://dx.doi.org/10.5465/AMR.2000.2791611

Schumpeter, J.A. (2008) The Theory of Economic Development: An Inquiry into Profits, Capital, Credit, Interest and the Business Cycle, translated from the German by Redvers Opie, New Brunswick (U.S.A) and London (U.K.): Transaction Publishers.

Stinchcombe, A. (1965) Social structures and organizations. Handbook of organizations. Rand McNally, Chicago.

Wiklund, Davidsson, Audrestch, Karlsson (2011) The Future of Entrepreneurship Research. Entrepreneurship Theory and Practice, 1, 1 9. DOl:http://dx.doi.org/10.1111/j.1540-6520.2010.00420.x

Zimmerman, M., Zeith, G. (2002) Beyond survival: achieving new ventures growth by building legitimacy. Academy of Management Journal, 3, 414-431. DOl:http://dx.doi.org/10.5465/AMR.2002.7389921

Zucker, L. (1987) Institutional theories of organization. Annual review of Sociology, 13, 443-464. 